\title{
International Surrogacy before the European Court of Human Rights
}

\begin{abstract}
:
Over the past fifteen years, international surrogacy has grown from a niche practice catering only to a few adventurous couples, to a convenient response to infertility for those who would otherwise be hindered by restrictive national regimes. While the Hague Conference on Private International Law continues to debate the desirability, and indeed viability, of an international convention in this area, governments and courts around the world have been confronted by the difficult question of whether to recognise an agreement that takes place legally in another jurisdiction, but which is contrary to their own laws. This paper will consider developments across Europe in regulating foreign surrogacy arrangements, in particular focusing on the recent decisions of the European Court of Human Rights of D v Belgium, Mennesson v France and Paradiso and Campanelli $v$ Italy, and their potential impact on national approaches. The paper will argue that in light of these decisions, the ability of domestic authorities to regulate international surrogacy is substantially undermined.
\end{abstract}

\section{Key words:}

international surrogacy, European Court of Human Rights, best interests of the child, public policy, recognition and enforcement 


\section{Introduction}

Throughout the world, we can see a multitude of different approaches to surrogacy, and a diversity of opinions concerning the commercialisation of the body, the potential exploitation of women, and the commodification of children. Even within Europe, a continent that has proclaimed shared values as to fundamental human rights, there is little common ground. While countries such as Ukraine, Russia, Greece and the United Kingdom have implemented legislative regimes to regulate domestic surrogacy, others such as Austria, France and Germany, prohibit any recourse to surrogate birth within their jurisdiction, either commercial or altruistic. Others still, such as Belgium, Czech Republic, Hungary, have no explicit legislation on the subject, and as such have used adoption law to construct makeshift rules.

Such divergent approaches to surrogacy have opened the door to circumvention tourism, where couples, and indeed individuals, who are restricted by domestic regimes travel to more permissive jurisdictions to achieve their goal of becoming parents. ${ }^{1}$ The question arises, however, as to how domestic authorities can, or should, respond to such actions when the parents and child return to the home state. In particular, how should authorities deal with surrogacy agreements that are carried out legally in other jurisdiction, but are contrary to the domestic law of the commissioning parents?

There have been various mechanisms introduced to curb the use of circumvention tourism in Europe, raising significant questions in terms of how to balance the rights of the commissioning parents, and the surrogate children, with state interests. Yet to date, only four cases have been decided before the European Court of Human Rights. These cases have dealt with three different mechanisms for restricting international surrogacy arrangements: (1) travel restrictions; (2) non-recognition of parenthood; and (3) and the removal into public care of children born through such practices. This article will explore how the Court has responded to each of these mechanisms, and whether we can see a coherent approach being taken by the Court in this respect. In doing so, it will demonstrate the difficult - indeed almost untenable situation faced by domestic authorities wishing to restrict surrogacy arrangements, and the implications of this for the future regulation of surrogacy throughout Europe.

\section{Regulation through travel restrictions}

The first difficulty that commissioning parents face in relation to international surrogacy agreements is to receive travel authorisation for children born through surrogacy to return with them to their home country. The difficulty here arises where the country of the child's birth assigns parenthood in a different manner to the domestic law of the commissioning parents, often leaving the child stateless, and without the ability to travel.

This was seen in the English case of $\operatorname{Re} X$ and $Y$ (Foreign Surrogacy), ${ }^{2}$ the first reported decision on international surrogacy in that jurisdiction. In this case, the commissioning parents travelled to Ukraine to undertake a commercial surrogacy agreement, paying the surrogate mother a monthly allowance, as well as $€ 25,000$ in compensation upon a live birth. When the children (twins) were born, and the commissioning parents wished to return home with them to England, their application for British passports for them were refused on the grounds that under English law, the legal parents of the children were the surrogate mother (as the woman who gave birth) and her husband. For this reason, the children were not British citizens, and the couple were advised to seek a passport from the Ukrainian authorities. However, upon application to the Ukrainian authorities, passports were also refused, as under Ukrainian law the commissioning parents were the legal parents, as the Ukrainian surrogacy regime permits

\footnotetext{
${ }^{1}$ In a 2010 study, it was found that $54.8 \%$ of patients travel for legal reasons (F Shenfield et al, "Cross border reproductive care in six European countries" (2010) 25(6) Human Reproduction 1361, 1368).

${ }^{2}$ [2008] EWHC 3030 (Fam).
} 
the commissioning parents to be entered directly onto the birth certificate, with no acknowledgement of the surrogate mother or the fact of surrogate birth. As such, the children were stateless, and unable to return to the United Kingdom until the Border Agency agreed to let them enter outside the immigration rules.

Similarly, in the German-Indian case of $\operatorname{Jan~Balaz}^{3}$ twin boys were born in India using the sperm of the German commissioning father and an egg from an Indian egg donor. On the birth certificate, the commissioning father's name was shown as the father, and the surrogate mother was named as the legal mother. When the commissioning parents sought to return to Germany, the authorities refused to issue a German passport or visa, as surrogacy arrangements are strictly prohibited under German law, and as such, recognition of parenthood arising from a surrogate birth was not permitted. ${ }^{4}$ The commissioning parents sought an Indian passport for the children, but the Government of India insisted that as the children were born to a surrogate mother, they were not entitled to Indian citizenship. After two years of litigation, the children were eventually granted Indian identity documents, and the German government made a one-time exception and issued visas to the children.

It was in the light of these not-infrequent occurrences that the legality of imposing travel restrictions on surrogate children was brought before the ECtHR in the case of Dv Belgium. ${ }^{5}$ This case concerned a Belgian couple who had travelled to Ukraine to enter into a surrogacy agreement. Upon the birth of the child, they applied to the Belgian authorities for a passport for him to return to Belgium with them, but this was refused due to lack of evidence provided concerning the genetic relationship between at least one of the couple and the child. There was no record of the pregnancy on the part of the commissioning mother (for obvious reasons), no information regarding a surrogacy agreement was provided, and the DNA tests provided to show the link between the commissioning father and child were from an internet site and "had no probative value". This refusal, and the subsequent proceedings before the courts until the necessary documents were finally produced (and the genetic link conclusively proved), resulted in a period of three months where the couple, no longer able to remain in Ukraine, had to return to Belgium without the child, leaving him to be cared for by a nanny.

The Court did not adjudicate on the compatibility of the original refusal to issue a travel document to the child with the Convention, as this matter had been solved by the time the case came to Strasbourg. Nor did it consider the question of the recognition of the Ukrainian birth certificate in Belgium, as this was still pending before the domestic courts at the time of the decision. However, the Court did examine the complaint concerning the separation of the parents and child while waiting for such document, which the applicants alleged contravened their right to respect for private and family life under Article 8. The Court accepted that the refusal of the Belgian authorities to immediately issue the child with travel documents, causing the separation, was motivated by the need to verify whether both Belgian and Ukrainian laws were respected, and found that such interference was justified by the legitimate aim of the prevention of crime, and in particular by the need to prevent trafficking in human beings.

In dismissing the application as manifestly unfounded, the Court held that the Convention does not oblige State Parties to authorise the entry into their territories of children born through a surrogacy arrangement without having undertaken relevant legal checks. ${ }^{6}$ Furthermore, the applicants could reasonably foresee the checks that they would face in order to bring the child to Belgium, especially as they had taken specialist legal advice. ${ }^{7}$ In coming to this decision, the Court found that domestic authorities are permitted to put in place legal checks and require

\footnotetext{
${ }^{3}$ Union of India v Jan Balaz (2015-10-121) Decided on 14 October 2015.

${ }^{4}$ But see below regarding current position.

${ }^{5}$ (Appl. No. 29176/13) Decision of 11 September 2014.

${ }^{6}$ At para 59.

${ }^{7}$ At para 60 .
} 
evidence to prove the genetic relationship between the parties, and the resulting separation of the parents and child in different countries until these have been completed is not contrary to Article 8.

While this case provided an interesting insight into the Court's views on international surrogacy, it ultimately raised more questions than answers. In particular, the Court held that the legal checks pursued the legitimate aim of, inter alia, ensuring that both Belgian and Ukrainian law had been complied with. Since Belgium does not regulate surrogacy arrangements explicitly, the only requirement was to prove a genetic link, and it was clear that permission to enter would have been granted eventually, although not speedily. But the question arises, how this would have been dealt with if the domestic jurisdiction in question explicitly prohibited surrogacy, as do, for example, France and Germany, and sought to permanently prevent entry of surrogate children? Could this public policy objection to surrogacy override the reunification of commissioning parents and a surrogate child, if those countries chose to legislate in this manner?

There is insufficient analysis in the decision to come to a conclusion on this issue, however, given the focus of the Court on the best interests of the child, it appears unlikely that such measures would be Convention-compliant. Where there is a genetic link between the commissioning parents and the child, and the parents cannot stay with the child in his or her country of birth due to immigration restrictions, it would appear to be a clear violation of the right to respect for family life if reunification were not permitted. ${ }^{8}$ The public order objection to surrogacy could not outweigh the consequences of such a decision - namely that the child would have to be placed in alternative care in the country of birth. As such, travel restrictions may be a legitimate way to screen children coming into the country for a genetic connection, but once this is established, it can serve no further purpose.

\section{Regulation through non-recognition of parental ties}

The second mechanism for regulating international surrogacy arrangements is through the refusal to legally recognise parental ties between the child and the commissioning parents. This has been the preferred mechanism in jurisdictions where surrogacy is explicitly prohibited for example, France, Germany and Spain.

In Germany, § 1(1) No. 7 German Embryo Protection Act and § 14b Adoption Placement Act prohibit both commercial and altruistic surrogacy, and courts faced with international surrogacy arrangements have taken the position that public policy has been violated by the mere fact that a surrogacy arrangement has been performed..$^{9}$ As such, the parenthood of commissioning parents has been refused recognition in Germany. ${ }^{10}$

Similarly, in Spain, Civil Registrars have only registered legal parenthood established by a foreign judgment if the judgment was first formally recognised by a Spanish Court. ${ }^{11}$ Spanish courts, for their part, have denied the recognition of parenthood arising from surrogacy, finding that filiation under Spanish law must be determined by birth, not intention. An example of this was seen in the refusal to register the birth certificate of a child born through surrogacy in the United States, which listed a homosexual couple as the parents. In its ruling, the court found that the problem was not that there were two fathers, but that the child was not born to either one of them. In response to the argument that registration must be allowed in the best interests

\footnotetext{
${ }^{8}$ And of Article 10 of the United Nations Convention on the Rights of the Child (1989).

${ }^{9}$ See Higher Regional Court Berlin 01.08.2013, Case $1 \mathrm{~W}$ 413/12, paras 26 et seqq. $=$ IPRax 2014, 72, 74 et seq.; Administrative Court of Berlin 05.09.2012, Case 23 L 283.12, paras 10 et seq. = IPRax 2014, 80 et seq. .

${ }^{10}$ This position has since changed following the decision in Mennesson - see Part 5 below.

${ }^{11} \mathrm{Id}$. See also part 5 below.
} 
of the child, the court admitted that this was a relevant factor, but emphasised that "the end does not justify the means". ${ }^{12}$

On the other hand, England also attempts to control surrogacy through the regulation of parenthood (albeit through a regulatory, rather than a prohibitive, scheme). Unlike other jurisdictions, however, English law does not recognise birth certificates issued abroad, and instead applies lex fori to the issue of parenthood. As such, legal parenthood is assigned to the surrogate mother at birth (and her husband, if he agrees to the treatment), and commissioning parents must apply to the court for parenthood to be transferred to them under s54 of the Human Fertilisation and Embryology Act 2008. ${ }^{13}$ When deciding whether to authorise this transfer, the English courts have taken a very different approach than their continental counterparts to the balance between public policy considerations and the best interests of the child. In the case of Re $X$ and $Y$ (Foreign Surrogacy), discussed above, Hedley J explained the reasoning process:

I feel bound to observe that I find this process of authorisation most uncomfortable. What the court is required to do is to balance two competing and potentially irreconcilably conflicting concepts. Parliament is clearly entitled to legislate against commercial surrogacy and is clearly entitled to expect that the courts should implement that policy consideration in its decisions. Yet it is also recognised that as the full rigour of that policy consideration will bear on one wholly unequipped to comprehend it let alone deal with its consequences (ie the child concerned) that rigour must be mitigated by the application of a consideration of that child's welfare. That approach is both humane and intellectually coherent. The difficulty is that it is almost impossible to imagine a set of circumstances in which by the time the case comes to court, the welfare of any child (particularly a foreign child) would not be gravely compromised (at the very least) by a refusal to make an order. ${ }^{14}$

In 2010, this approach was strengthened by the Human Fertilisation and Embryology (Parental Orders) (Consequential, Transitional and Saving Provision) Order, ${ }^{15}$ which introduced the requirement that the child's welfare be the paramount, rather than simply the primary, consideration, when deciding whether to transfer parenthood to commissioning parents. As Hedley J emphasised in the case of Re L (Commercial Surrogacy), the effect of this change was

to weight the balance between public policy considerations and welfare ... decisively in favour of welfare. It must follow that it will only be in the clearest case of the abuse of public policy that the court will be able to withhold an order if otherwise welfare considerations support its making. ${ }^{16}$

In this way, the English courts have transferred legal parenthood to the commissioning parents, despite breaches of law including large payments to surrogate mothers, as well as to agents and

\footnotetext{
12 Marta Requejo, "Surrogate Motherhood and Spanish Homosexual Couple (III)" (20 September 2010) http://conflictoflaws.net/2010/surrogate-motherhood-and-spanish-homosexual-couple-iii/.

${ }^{13}$ For a more comprehensive discussion of the way in which the courts have applied this section, see Claire Fenton-Glynn, "The Regulation and Recognition of Surrogacy in English Law" (2015) 27(1) Child and Family Law Quarterly 83.

${ }^{14}$ Ibid, at para 24.

${ }^{15}$ SI 2010/986.

${ }^{16}$ [2010] EWHC 3146 (Fam), [2011] 1 FLR 1423, at para 10.
} 
mediators, ${ }^{17}$ applications outside the time limit, ${ }^{18}$ deception of the Foreign Office, ${ }^{19}$ and lack of truthful information about the surrogate mother. ${ }^{20}$

In July 2014, the European Court of Human Rights weighed into the debate concerning the balance to be struck between children's rights and public order considerations surrounding surrogacy arrangements, in the case of Mennesson $v$ France. ${ }^{21}$ The facts in the case follow a pattern that is now sadly familiar: an infertile couple, unable to enter into a surrogacy arrangement in their home country, seek out a more permissive jurisdiction in order to fulfil their wishes of becoming parents.

As with Germany, French domestic law does not permit surrogacy, with Article 16-7 of the French Civil Code stating that "[a]1l agreements relating to procreation or gestation of a third party are void", and Article 16-9 making this a prohibition of public order, which as such cannot be derogated from. ${ }^{22}$ Furthermore, under the French Criminal Code, recourse to surrogacy is punishable by one year's imprisonment and a fine of $€ 15,000$.

In Mennesson, a French couple had travelled to California to enter into a surrogacy agreement. After successful a birth of twin children, the Californian court recognised the parenthood of the couple, and they returned to France with the children. While the French authorities initially entered the births onto the French register for births, marriages and deaths, the public prosecutor brought proceedings to have this annulled. He argued, and the Cour de Cassation agreed, that recording such entries would give effect to a surrogacy agreement that was null and void under French law, and recognise a practice that the legislature had expressly forbidden. ${ }^{23}$

This was hardly surprising, as the Cour de Cassation had previously denied the registration of birth certificates issued in India following surrogate births, on the grounds that this would result in a "fraud" under French law. ${ }^{24}$ In one case, the Court went even further and held that not only is a surrogacy contract prohibited by French law, but as the father had paid $€ 1,500$, it constituted the purchase of a child. The Cour de Cassation found that "in the face of this fraud, neither the best interests of the child guaranteed by Article 3 of the UNCRC, nor the respect for private and family life under Article 8 of the ECHR, can be successfully invoked." 25

After the annulment of the registration of the children's birth, the couple brought a case before the ECtHR, claiming that the inability to obtain recognition in France of their parent-child relationship, which had already been established abroad, infringed on their right to respect for private and family life under Article 8 ECHR.

The Court recognised that surrogacy raises difficult ethical issues, and emphasised the lack of consensus in Europe as to how to respond to this practice, both domestically and abroad. In light of this, the Court held that, in principle, States must be given a wide margin of discretion with regard to the decision of whether or not to allow this method of reproduction, as well as

\footnotetext{
${ }^{17} \operatorname{Re} P M$ [2013] EWHC 2328 (Fam); [2014] 1 FLR 725

${ }^{18} \operatorname{Re} X$ (A Child) [2014] EWHC 3135 (Fam). See Claire Fenton-Glynn, "The Difficulty of Enforcing Surrogacy Regulations" (2015) 74(1) Cambridge Law Journal 34.

${ }^{19} \operatorname{Re} C$ (Parental Order) [2013] EWHC 2413 (Fam), [2014] 1 FLR 654.

${ }^{20} \operatorname{Re} D$ (A Child) [2014] EWHC 2121 (Fam); Re D and L (Minors) (Surrogacy) [2012] EWHC 2631 (Fam); [2013] 2 FLR 275. See Claire Fenton-Glynn, "The Regulation and Recognition of Surrogacy under English law” (2015) 27(1) Child and Family Law Quarterly 83.

${ }^{21}$ (Appl. No. 65192/11) Judgment of 26 June 2014. This case was heard simultaneously with Labassee v France (Appl. No. 65941/11) Judgment of 26 June 2014.

${ }^{22}$ Under Article 6 of the Civil Code "Statutes relating to public policy and morals may not be derogated from by private agreements".

${ }^{23}$ See Mennesson, at part D.

${ }^{24}$ Cass. 1ère civ.; 12-18315. See Mennesson, at para 25.

${ }^{25}$ Cass. 1ère civ.; 12-30138.
} 
whether to recognise parenthood arising from foreign surrogacy arrangements. However, the Court was also swift to assert that "the choices made by the State, even within this margin of appreciation, are not beyond the control of the Court." 26

The Court took a very unsympathetic approach to the claims of the applicants. While it recognised the difficulties that could be encountered in having to produce an American birth certificate whenever they wish to access services that require proof of parentage - for example, in receiving family allowances, registering the child under the social security of their parents, and school enrolment - it held that the practical obstacles that they had actually had to overcome so far had not been insurmountable, and that the applicants had failed to demonstrate that the failure to obtain recognition of their parentage had hampered the enjoyment of their respect for family life. ${ }^{27}$ Taking a broad-brush approach, the Court pointed out that they had been able to establish themselves in France, and were able to live together in a situation broadly comparable to the conditions of other families, and emphasised that there was no risk that the authorities would separate them on the basis of their status under French law. ${ }^{28}$ As such, and in light of the margin of appreciation given to the French authorities, it held that there was a fair balance struck between the interests of the applicants and those of the state. ${ }^{29}$

The reasoning in this respect was rather slim, and there was a clear lack of sympathy for the commissioning parents for having, as the Court considered, brought this on themselves. The Court relied on the fact that the difficulties faced were not overwhelming, and largely concerned only issues that may arise in the future - for example, if the parents separated, or the genetically related parent died. However, while the court was influenced by the fact that the parents had deliberately circumvented domestic law, it emphasised that it was the parents alone who made this choice, and that the children were innocent parties. Following on from recent case-law concerning the primacy of children's rights, ${ }^{30}$ the Court reiterated that in striking a fair balance between the interests of the state and the child, the child's best interests must prevail. ${ }^{31}$

The Court focused on the right to respect for private life on the part of the children, emphasising that this encompasses the right to establish details of one's identity, as well as the recognition of the legal parent-child relationship. ${ }^{32}$ Noting the lack of clarity regarding the children's legal status, the Court observed that they faced uncertainty concerning the possibility of obtaining French nationality, which undermined their identity within French society. ${ }^{33}$ It noted that nationality and a right to inheritance were also important elements of a children's identity, and these had been compromised by the refusal to recognise parenthood. ${ }^{34}$ Although the children's genetic father was French, they were unable to obtain French nationality, and they were only able to inherit from the commissioning parents as legatees, rather than as descendants.

As such, the Court considered that their situation was liable to have negative repercussions on the definition of their identity. It found that "[g]iven the importance of biological parentage as part of one's identity, one cannot claim that it is in the interests of a child to deprive him of a legal relationship of this nature while the biological reality of this link is established, and the child and parent concerned demand full recognition." ${ }^{35}$ Thus the genetic link with the father was framed as the crucial component in the creation of an interest in private life for the child -

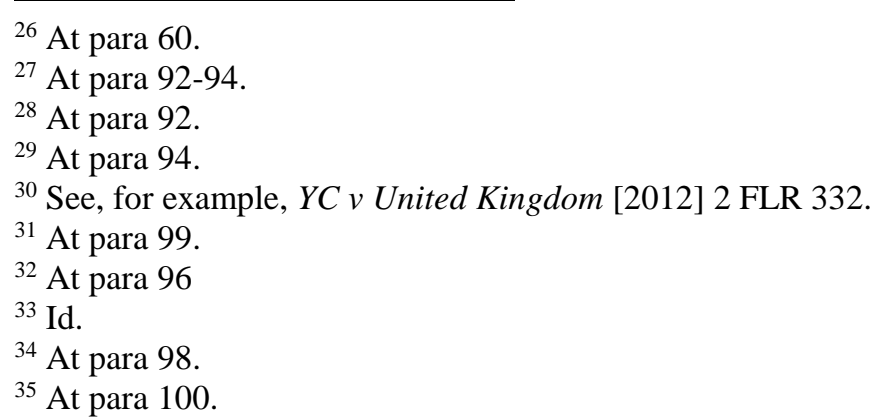


a factor that went on to have great importance in the following case of Paradiso and Campanelli v Italy. ${ }^{36}$

While the lack of consistency and consensus between Member States on artificial reproductive technology, and the sensitive moral and ethical issues raised, meant that domestic authorities have a wide margin of appreciation in this field, the Court emphasised that this would be limited where a particularly important facet of an individual's existence or identity is at stake. ${ }^{37}$ States must not only find a balance between the interests of the community and those of the applicants, but in doing so must uphold the best interests of the child. For these reasons, the Court found that France had surpassed its margin of appreciation in respect of the children in its refusal to recognise the relationship already established, and was thus in violation of Article 8. This decision was expressly approved in Foulon and Bouvet v France, ${ }^{38}$ where the Court reiterated that the children's rights to respect for private life had been violated by the refusal to transcribe their Indian birth certificates onto the French register, on the grounds that they were the result of surrogacy arrangements.

The decision in these cases is hardly surprising, as it follows the previous ECtHR jurisprudence on the recognition of foreign adoption decisions. In particular, it echoes the decision of Wagner and JMWL $v$ Luxembourg $^{39}$ in which a refusal to recognise an intercountry adoption was found to be a breach of the child's rights under Article 14 in conjunction with Article 8 .

This case involved a single woman who was a Luxembourger citizen, who travelled to Peru to adopt a child. The adoption order was granted by the Peruvian provincial family court, but the mother's attempt to have this recognised as a full adoption in Luxembourg failed, as only simple adoptions were available to single persons. The applicant argued that the distinction between married and single adopters was discriminatory and thus in contravention of Article 14 in conjunction with Article 8 ECHR. The government, on the other hand, contended that the distinction had the legitimate aim of protecting the child, as two parents were better able to care for an adopted child, especially one who had come from aboard and had been uprooted from everything he or she knew. ${ }^{40}$ The ECtHR based its findings under Article 14 not on the claims of the mother not to be discriminated against - as she had argued - but focused on the situation of the child not to be treated differently from other children who had been the subject of a judgment of full adoption in Peru resulting in a complete break from the family of origin. It held that although these genetic ties had been legally broken, because of the decision of the Luxembourg authorities, no alternative legal link had been forged with the adoptive mother, leaving the child in a legal vacuum.

Thus the reasoning of the court in Wagner is substantially similar to that in Mennesson. Where parental ties have been broken in the country of birth - as they usually are in cases of surrogacy - to deny the formation of new legal ties with the person (or persons) who will now act as parents would be to undermine the child's right to certainty of legal status, and to identity.

While the outcome may not have been surprising, the case is a watershed moment for the regulation of international surrogacy in Europe. In effect, it means that once the surrogacy has taken place and the child was legally relinquished to the commissioning parents in the country of birth, recognition of the relationship in their home country cannot be denied. For the many countries that completely prohibit domestic surrogacy, this means denial of status can no longer be used as a deterrent against the use of international surrogacy arrangements.

\footnotetext{
${ }^{36}$ See below at part 4 .

${ }^{37}$ At paras 75-80.

38 (Appl. Nos. 9063/14 and 10410/14) Judgment of 21 July 2016.

39 (Appl. No. 76240/01) Judgment of 28 June 2007.

${ }^{40}$ Wagner and JMWL v Luxembourg, at para 146-147.
} 


\section{Regulation through child protection mechanisms}

The third set of circumstances in which international surrogacy has come before the European Court of Human Rights involved a rather drastic approach to preventing international surrogacy by the Italian authorities, which has not been seen in other jurisdictions - the removal of the child from the commissioning parents, and his placement for adoption.

The case of Paradiso and Campanelli $v$ Italy ${ }^{41}$ concerned an Italian husband and wife who, after many failed attempts to have a child using IVF treatment, decided to enter into a surrogacy arrangement to become parents. As Italian Law prohibits surrogacy arrangements within its our jurisdiction, and criminalises anyone who produces, organises or advertises surrogacy in any form, ${ }^{42}$ the couple travelled to Russia to undertake the arrangement.

When the child was born, and the surrogate mother gave her consent, the child was registered with the commissioning parents listed on the birth certificate as legal parents, without any indication that the child had been born through a surrogacy arrangement. The Italian Consulate in Moscow issued travel documents allowing the child to return to Italy, but when the commissioning parents asked the Italian municipal authorities where they lived to register the birth, the Consulate informed the municipality that the file on the child's birth contained false information. The commissioning parents were charged with "misrepresentation of civil status", as under Italian law the legal mother is the person who gave birth to the child, contrary to what the couple were trying to register. They were also charged with a violation of adoption legislation, in that they had brought a child to Italy without complying with the authorisation to adopt. While they had been given previous authorisation to adopt a child in 2006, this limited them to older children only.

On the same date, the Public Prosecutor opened proceedings to free the child for adoption on the grounds that, according to Italian law, the child had been abandoned. The child's surrogate mother had ceased to care for him when she handed him to the commissioning parents, and a DNA test revealed no genetic link between the commissioning father and the child - gametes from other sources having been used in the course of the fertilisation procedure - leaving him with no known genetic parents. In the subsequent proceedings, the Minors Court found that the child should be removed immediately from the commissioning parents and placed under guardianship, basing its decision on doubts as to their child-raising and emotional capacities, since they had deliberately circumvented Italian law in order to pursue their "narcissistic desire" to have a child. As such, the child was placed with foster parents, and by the time of the hearing before the ECtHR, was in the process of adoption proceedings.

The case was first heard by the second Chamber of the ECtHR, which took a very sympathetic approach to the position of the commissioning parents, in stark contrast to the language used in Mennesson. The Court noted that "it cannot ignore the emotional aspects of the case", citing their inability to procreate naturally, their applications for adoption, and their waiting period of several years to be able to adopt when there was a shortage of adoptable children. ${ }^{43}$ The Court went on to suggest that they "nurture[d] hope" when they entered into the surrogacy arrangement and "experience[d] despair" when they learnt that the child was not genetically related to them. ${ }^{44}$ Despite this, they found that the Italian courts had not been unreasonable in strictly applying national law to determine parentage, and finding that the applicant's good faith could not replace the necessary genetic link.

\footnotetext{
${ }^{41}$ (Appl. No. 25358/12) Judgment of 27 January 2015.

${ }^{42}$ Law 40/2004.

${ }^{43}$ At para 77.

${ }^{44}$ Id.
} 
This sympathy for the applicants can perhaps explain the Court's finding that there was "de facto" family life between themselves and the surrogate child, despite the lack of genetic link, thus bringing the action under the scope of "family life" under Article $8 .{ }^{45}$ Relying on the fact that "the applicants spent time with the child during the important first steps of his young life" 46 - for the first eight months of his life, he had lived with the applicants - the Court found that although the period was relatively short, during that time they behaved towards the child as parents, and therefore there was de facto family life between them. They emphasised the fact that the applicants wished to care for the child as his parents, and had taken steps to achieve this, and in this way, a parental link was formed between the parents and child.

Having recognised the ties of family life between the commissioning parents and child, the case was essentially transformed into one concerning the balance between familial autonomy and state intervention. That is, in what circumstances can the state remove a child from the family home, whether or not that "family" has been legitimately formed under domestic law. In this respect, the Italian courts had found that the child was without an adequate family environment, given that the child was born to unknown genetic parents, and that the surrogate mother had abandoned him. It attached great weight to the situation of illegality brought about by the commissioning parents by bringing the child into Italy, in breach of the law on international adoption and the law on assisted reproduction. They held that the commissioning parents had shown a willingness to circumvent domestic law by approaching the Russian surrogacy clinic, which showed a narcissistic desire on their part, where the child was intended to solve their problems as a couple. This in turn cast doubt on their emotional and educational capacities. The approach of the Italian courts was to focus on the need to put an end to the illegal situation, and thus it was necessary to remove the child from the applicants' home, and from any possibility of contact with them. ${ }^{47}$

However, the ECtHR held that reference to public order cannot give domestic authorities carte blanch to justify any action, because there is an obligation to take into account the child's best interests, "irrespective of the nature of the parental link, genetic or otherwise." 48 The Court held that removal of a child form the family environment is an extreme measure that should only be used as a last resort. For this type of measure to be justified, it must be responding to an immediate danger confronting the child. ${ }^{49}$ The conclusions of the domestic courts that the commissioning parents were unsuitable as they had circumvented Italian law to undertake a surrogacy arrangement were insufficient, especially given the fact that the commissioning parents had previously been approved as prospective adopters.

The recognition of "family life" by the Chamber, in spite of the lack of genetic connection, was a dangerous extension of the concept of "de facto" family ties, and risked creating an unfortunate precedent. While social parenthood has long been recognised to be sufficient to constitute a "family", the social parenthood in this case was created in contravention of legal rules. The Italian law prohibits parenthood through surrogacy, and indeed regards it as a criminal offence, yet the ECtHR appeared to regard that as irrelevant in establishing family life. Furthermore, family life was found to have been established after a period of eight months in which the commissioning parents cared for the child. Given that in many countries there is no

\footnotetext{
${ }^{45}$ At para 69. The Court also found that the couple's private life was involved. It held that respect for private life requires that everyone can work out the details of his identity as a human being, and the right of an individual to such information is vital because of its impact on the formation of the personality. In the present case, the applicant had sought to establish whether he was a father: his application for recognition of filiation, legally established abroad, was coupled with a search for the genetic truth - to determine his relationship with the child. Consequently, the court found a direct relationship between the establishment of filiation and the applicant's private life.

${ }^{46}$ At para 69.

${ }^{47}$ At para 79.

${ }^{48}$ At para 80.

${ }^{49} \mathrm{Id}$.
} 
obligation to register a foreign birth certificate, the applicants can basically play a waiting game with the authorities to secure their desired outcome, regardless of the legality of their original actions.

This line of reasoning was criticised heavily by Judges Raimondi and Spano in dissent, who argued that in deciding whether family life exists, the court should take into account the circumstances in which the child has been placed in the custody of the persons concerned, when deciding whether or not de facto family life has been developed. They emphasised that Article 8 (1) cannot be interpreted as protecting family life between a child and people with whom he or she has no genetic link where the facts clearly suggest that the origin of their care is based on an illegal act contrary to public order. ${ }^{50}$

An analogy here can be drawn with a child kidnapped at birth, and brought up to consider the kidnappers as his or her parents. In both cases, the putative "family life" arises from an illegal situation, contrary to domestic law. But few would argue that such family life should be protected in the case of a kidnapping. What then is the difference in relation to surrogacy? If the domestic law views surrogacy as a violation of human dignity, exploitation of women, and trafficking in children, as many jurisdictions do, is a "family" formed through such exploitation, commodification and denigration any more worthy of recognition than one formed through kidnap? Or is the Court in this case imposing its own moral views on surrogacy on Member States? As the judges in dissent point out, the position of the majority amounts in essence to a denial of the legitimacy of the choice of the state not to recognise surrogacy arrangements, and to view them as immoral and illegal. If illegally creating a link with a child abroad is sufficient for the national authorities to be required to recognise the existence of "family life", they argued, it is clear that the freedom of states not to recognise the legal effects of surrogacy is reduced to nothing. ${ }^{51}$

It was this dissenting reasoning that was followed by the Grand Chamber, when it decided the case in January 2017. By a majority of eleven votes to six, the Court held that the removal of the child did not violate Article 8, as there was no relevant family life between the couple and the child. ${ }^{52}$

The Court accepted that, in certain situations, de facto family life could arise in the absence of either genetic or legal ties, provided that there are genuine personal ties. ${ }^{53}$ In such a case, the court must consider the quality of the interpersonal ties, the role played by the applicants visà-vis the child, and the duration of the cohabitation between them and the child. ${ }^{54}$ Although the Court declared that it would be inappropriate to define a minimal duration of cohabitation, it nevertheless identified it as a key factor in the Court's recognition of family life. ${ }^{55}$ In this way, the Court distinguished the case from that of Wagner and JMWL, discussed above, where the child had already lived with the adoptive mother for over ten years.

The Court held that although the termination of their relationship with the child was not directly imputable to the applicants, it was nevertheless the consequences of the legal uncertainty that they themselves created in respect of the family ties, by engaging in conduct that was contrary to Italian law. ${ }^{56}$ As such, the quality of the emotional bonds forged between the applicants and

\footnotetext{
${ }^{50}$ Joint partly dissenting opinion of Judges Raimondi and Spano, at para 3.

${ }^{51}$ Ibid, at para 15.

52 Judgment of 24 January 2017.

${ }^{53}$ At para 148.

${ }^{54}$ At para 151.

${ }^{55}$ At para 152.

${ }^{56}$ This was in contrast to cases where de facto family life had been recognised (eg Wagner), and also cases concerning foster parents (Kopf and Liberda v Austria (Appl. No. 1598/06) Judgment of 17 January 2012; Moretti and Benedetti v Italy (Appl. No. 16318/07) Judgment of 27 April 2010), where the authorities had recognised, or tolerated, the child's placement with the applicants.
} 
the child was not enough to outweigh the lack of genetic tie, the short duration of the relationship, and the legal uncertainty of the ties, all of which amounted to an absence of "family life". ${ }^{57}$ The applicants then had to fall back on the protection of "private life" under Article 8, which in such cases, is easier to displace as necessary and proportionate.

The Court accepted that the reasons put forward by the authorities - to put an end to illegal conduct, and to take measures urgently concerning child who was "in a state of abandonment" - were relevant to the legitimate aim of preventing disorder and the protection of children. It emphasised that the protection of children went beyond the individual child in this case, but also applied to children more generally, through the prerogative of the State to prohibit certain techniques of medically assisted reproduction. ${ }^{58}$ The reasons were also sufficient - it was not the preservation of a family unit that was at stake, but the applicants' right to personal development, which was more easily interfered with.

This right to personal development, when balanced against the "very weighty interests" 59 of public policy, was found to be wanting. Focusing once again on the illegality of the situation, the Court held that "[a]greeing to let the child stay with the applicants, possibly with a view to becoming his adoptive parents would have been tantamount to legalising the situation created by them in breach of important rules of Italian law." ${ }^{60}$ As such, the interference with the couple's private life was proportionate to the legitimate aim pursued.

While this judgment was carefully reasoned and showed deference to differing views concerning the ethical considerations relating to surrogacy, the same cannot be said of the concurring opinion of Judges de Gatano, Pinto de Albuquerque, Wojtyczek and Dedov. In a polemical discourse, they declared that the child in this case had been "a victim of human trafficking. He was commissioned and purchased by the applicants." ${ }^{\prime 11}$ Relying on the Optional Protocol to the Convention on the Rights of the Child on the Sale of Children, Child Prostitution and Child Pornography, the judges argued that the definition of "sale of children" is broad, and encompasses transactions of children for remuneration irrespective of their purposes, and including the transfer of parental rights over children..$^{62}$ In support of this conclusion, the judges drew on Concluding Observations from the UN Committee on the Rights of the Child, where the Committee had informed the United States that "[t]he absence of federal legislation with regard to surrogacy, which if not clearly regulated, amounts to sale of children;" ${ }^{33}$ However, they went further than the Committee, and stated that "remunerated gestational surrogacy, whether regulated or not, amounts to a situation covered by ... the Optional Protocol to the Convention on the Rights of the Child and is therefore illegal under international law." 64 Moreover, they declared that gestational surrogacy is incompatible with human dignity, and constitutes degrading treatment, not only of the child, but also of the surrogate mother ${ }^{65} \mathrm{In}$ gestational surrogacy, "[b]oth the child and the surrogate mother are treated not as ends in themselves, but as means to satisfy the desires of other persons." ${ }^{166}$ Such a practice, they argued, is not compatible with the values underlying the Convention.

If possible, the concurring opinion of Judge Dedov is even more virulent in its criticism of surrogacy. He argued that in order to prevent the "moral and ethical degradation of society" the Court should speak out against practices that undermine Convention values of, inter alia,

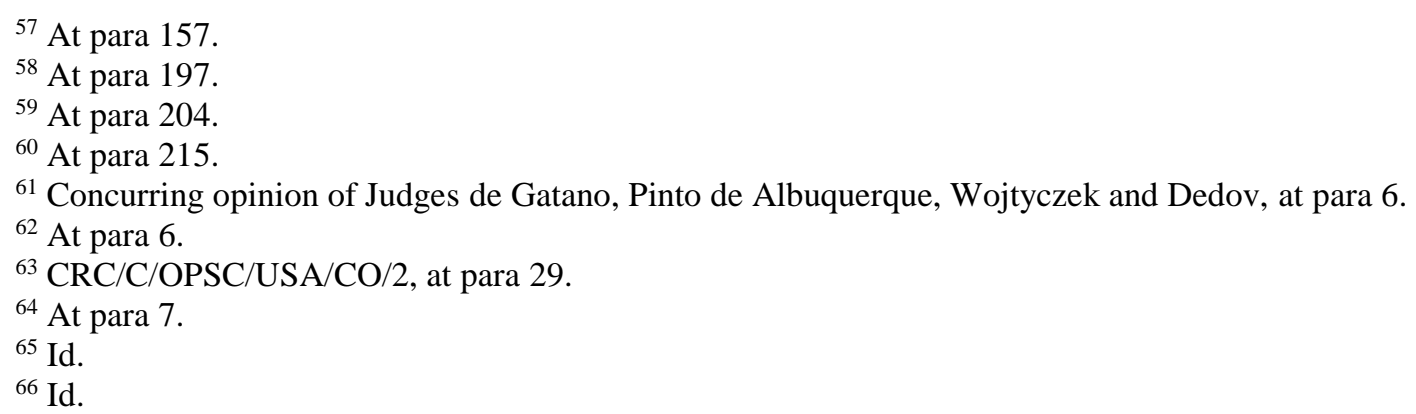


dignity, integrity, equality, and inclusiveness, rather than "hide behind" the margin of appreciation. Ultimately, he said "surrogacy presents one of those challenges when we must ask ourselves who we are - a civilisation or a biomass? - in terms of the survival of the human race as a whole." ${ }^{67}$ Whether or not we agree with Judge Dedov's comments concerning surrogacy, this call to arms from the Russian judge highlights a tension between the role of the Court as a human rights body, and its position as a supranational entity that relies on political cooperation for compliance, and indeed legitimacy. The use of the margin of appreciation to avoid taking strong stands on issues may be politically expedient, and ensures the Court's continued existence, but it can also result in an abdication of responsibility for making hard decisions on ethically contentious issues.

Another flaw in the system of the European Court was highlighted by the decision in Paradiso - both at the Chamber and Grand Chamber level. One of the most significant differences between the cases of Mennesson and Paradiso, and one which had a significant bearing on the outcome, was the fact that the commissioning couple in Mennesson were able to bring a complaint before the ECtHR on behalf of the child. While the couple in Paradiso also attempted to do so, they were found not to have standing, as they had no genetic connection to the child, were not his guardians, and were not his representatives under domestic law. This meant that the case was fought on narrower grounds than that of Mennesson, and it lacked the focus on the specific rights of the child, rather than simply his "best interests" in light of adult actions. In this way, the child, who should have been at the centre of the case, was reduced to an object, rather than subject, of rights.

The Grand Chamber judgment in Paradiso will have lasting implications for the evaluation of the existence of de facto family life under Article 8. However, in terms of the regulation of surrogacy, its impact is less significant. While it leaves some scope for the state to restrict surrogacy arrangements, the very fact that the emphasis was placed so heavily on the lack of genetic connection itself reinforces the decision in Mennesson, and the inability of States to act where the gametes of the commissioning parents have been used. This ties in with the admissibility decision of $D v$ Belgium, finding that states are permitted to put in place legal checks to prove the genetic relationships between the parties, before allowing the child entrance to the country. It appears that the Court has deemed the genetic link to be necessary and sufficient to provide protection - once it is proved, the child must be allowed to enter the country, and the parent-child relationship has to be legally recognised. Without it, States can separate the commissioning parents and child, either through travel restrictions, or through child protection mechanisms.

\section{European developments}

While Paradiso may not itself have significant impact on the regulation of surrogacy in Europe, the immediate effect of Mennesson on domestic law has been dramatic. In France, there was initial political resistance against the decision, with the Prime Minister, Manuel Valls, declaring in October 2014 that the recognition of children born through surrogacy would remain prohibited in France, despite the decision. ${ }^{68}$ As such, when the High Court ordered the registration of three children born through surrogacy in May the following year, the public prosecutor appealed, relying once again on the fact that such a recognition would be contrary to public order. However, in July 2015, the matter came again before the Cour de Cassation, which found that the ECtHR judgment must be followed. The Court found that a birth certificate issued in a foreign country must be transcribed into the French civil register, unless evidence

\footnotetext{
${ }^{67}$ Concurring opinion of Judge Dedov.

${ }^{68}$ Le parquet de Nantes fait appel de l'inscription a l'état civil de trois enfants nés par GPA a l'étranger (18 May 2015) http://www.lemonde.fr/societe/article/2015/05/18/le-parquet-de-nantes-fait-appel-de-1inscription-a-1-etat-civil-de-trois-enfants-nes-par-gpa-a-1etranger_4635718_3224.html?xtmc=gestation_pour_autrui\&xtcr=1.
} 
suggests that the document is irregular, falsified, or the facts stated on it do not correspond to reality. ${ }^{69}$

A similar position has been adopted in Spain, which has had a very unsettled approach to the recognition of foreign surrogacy. Prior to 2010, Civil Registrars in Spain had registered legal parenthood established by a foreign judgment only if the judgment had first been formally recognised by a Spanish court - as outlined above. However, in 2010 the Direccion General de los Registros y del Notariado (the administrative body in charge of the civil register) issued a resolution, instructing registrars that prior recognition of the foreign judgment by a Spanish court was no longer necessary. Instead, as long as certain conditions procedural conditions were met, the Registrar was competent to pronounce the authenticity of the foreign judgment and register the birth. These included that the foreign judgment had been issued in uncontested proceedings, the procedural rights of the surrogate had been protected, that there was no infringement of the best interests of the child, and the surrogate mother had given her consent to freely. However, the resolution indicated that there was no requirement that the registry confirm that the foreign judgment was not contrary to Spanish public policy. ${ }^{70}$

This resolution was reversed in February 2014, when the Supreme Court held that the Civil Registry has an obligation to examine not only the authenticity of the birth certificate, but also whether it was contrary to public policy. However, in response to Mennesson, the Direccion General de los Registros y del Notariado has issued a Circular stating that the 2010 resolution must now be applied, regardless of the Supreme Court decision. This leaves the law in a somewhat uncertain position, however the Spanish Minister for Justice announced in December 2014 that an amendment was planned to the new Civil Registries bill that would ensure the compliance of Spanish law with Mennesson. ${ }^{71}$

Finally, the ECtHR jurisprudence has also been influential in the recent change in approach to recognition of foreign surrogacy arrangements in Germany. As discussed above,${ }^{72}$ German domestic law prohibits both commercial and altruistic surrogacy, and courts had shown a tendency to regard public policy as violated by the mere fact that surrogacy had been performed. However, in December 2014, the German Federal Court of Justice held that, following the ECtHR jurisprudence, the welfare of the child must be the primary consideration, and recognition of the foreign birth certificate must follow. ${ }^{73}$ The Court recognised the general preventative aims of the legislation, but emphasised that once the child was born, there was little that could be done. As with Mennesson, it held that the child could not be held responsible for the circumstances of his or her birth, and a denial of recognition was too great a punishment. ${ }^{74}$

69 Cour de Cassation, Ruling no. $619 \quad$ (3 July 2015), https://www.courdecassation.fr/cour_cassation_1/in_six_2850/english_2851/the_transcription_7252/ru ling_no._619_32234.html.

${ }^{70}$ See Patricia Orejudo Prieto de Los Mozos, "National Report: Spain", in Katarina Trimmings and Paul Beaumont, International Surrogacy Arrangements (Hart, 2013).

${ }^{71}$ Hague Conference on Private International Law, "The Parentage/Surrogacy Project: An Updating Note" (February 2015), https://assets.hcch.net/docs/82d31f31-294f-47fe-9166-4d9315031737.pdf, at para 3. See also, Paul Beaumont and Katarina Trimmings, "Recent Jurisprudence of the European Court of Human Rights in the area of cross-border surrogacy: is there still a need for global regulation of surrogacy?" (2015, Working Paper).

${ }^{72}$ See part 3 above.

${ }^{73}$ Case XII ZB 463/13 (10 December 2014), http://juris.bundesgerichtshof.de/cgibin/rechtsprechung/document.py?Gericht=bgh\&Art=pm\&Datum=2014\&Sort=3\&nr=69759\&linked=b es\&Blank=1\&file=dokument.pdf.

${ }^{74}$ See Nora Markard, "German Supreme Court Recognises Same-Sex Parents after Californian Surrogacy" (11 January 2015), http://www.sexualorientationlaw.eu/102-german-supreme-courtrecognizes-same-sex-parents-after-californian-surrogacy-germany. 
This judgment was of particular importance as the Court carefully examined the other alternatives that could have been pursued. First, responding to the suggestion that the surrogate mother be recognised as the legal parent, the court noted that even if this did occur, it would have no effect on the status of the surrogate mother herself, as in her own jurisdiction, she was not recognised as such. In this way, it would deprive the child of any real legal parent in either jurisdiction, and be contrary to his or her rights under Article 8 . The Court also ruled out adoption as an appropriate mechanism, as it would leave the commissioning parents with discretion as to whether they assumed parental responsibilities for the child, or changed their mind. Moreover, the country of the child's birth already considered the applicants as the legal parents, which would mean that an intercountry adoption would not be possible. ${ }^{75}$

As such, we can see that the developments in ECtHR jurisprudence have had a direct impact on the recognition of international surrogacy arrangements in Europe. While this is to be expected, the more subtle effect will be in the longer term, and their impact on domestic regulation.

\section{The potential implications for domestic surrogacy}

The decisions in these cases introduce an almost laissez-faire approach to international surrogacy, albeit not driven by concerns about government interference, but rather the imperative of individual rights. But what do they mean for domestic surrogacy regimes?

The most obvious consequence of these cases is the dual treatment of surrogacy arrangements in these jurisdictions. While domestic arrangements are still prohibited and unrecognised, parenthood achieved through international surrogacy arrangements must be respected - at least where there is a genetic connection. As a result, those with financial means can choose another regulatory scheme, and thus avoid the restrictions put in place by domestic authorities, in effect buying their way out of the ethical decisions given legislative force in their own jurisdiction. ${ }^{76}$ This was highlighted by Judge Dedov in his concurring opinion in the Grand Chamber judgment in Paradiso, where he argued:

The statistics and the facts of the surrogacy cases examined by this Court demonstrate that surrogacy is carried out by poor people or in poor countries. The recipients are usually rich and glamorous. Moreover, the recipients usually participate in or decisively influence the national parliament. Moreover, it is extremely hypocritical to prohibit surrogacy in one's own country in order to protect local women, but simultaneously to permit the use of surrogacy abroad. ${ }^{77}$

This discrimination between domestic and international practice may affect domestic surrogacy regimes in one of two ways. First, it may lead to stricter domestic laws than would otherwise be the case. As Storrow suggests, "[t]hose who desire a procedure are apt to be less concerned about whether it becomes outlawed, at least if they have the means to travel in order to acquire it. Those who wish to prohibit the procedure may feel justified in assuming a harsher position than they otherwise might, knowing that cross-border reproductive care will temper resistance to the law." 78

\footnotetext{
${ }^{75} \mathrm{Id}$.

${ }^{76}$ See TK Hervey, "Buy baby: the European Union and regulation of human Reproduction" (1998) 8 Oxford Journal of Legal Studies 207.

77 (Appl. No. 25358/12) Judgment of 24 January 2017. On this point, see C Fenton-Glynn,

"Outsourcing Ethical Dilemmas: Regulating International Surrogacy Arrangements" (2016) 24(1)

Medical Law Review 59.

${ }^{78}$ RF Storrow, "The Pluralism Problem in Cross-Border Reproductive Care" (2010) Human Reproduction 1, 1 .
} 
This was the argument used by the Grand Chamber of the ECtHR in the case of SHv Austria. ${ }^{79}$ Austrian law forbids ova donation under all circumstances, and only allows sperm donation where it is used for in vivo, as opposed to in vitro, fertilisation. When considering the compliance of Austrian law with the ECHR, the possibility for couples to go abroad for treatment contributed to the finding that the ban could be considered proportionate. The implication is that Austria was permitted to impose more restrictive laws that would otherwise be the case, as individuals could always go to another jurisdiction to avoid them.

On the other hand, however, as a moral and ethical issue, the responses to which are rapidly developing, the requirement to recognise international surrogacy agreements might equally provide the impetus to relax domestic law, leading to the gradual abandonment of restrictive domestic approaches. Where surrogacy arrangements abroad must be recognised, states may move towards an acceptance of all surrogacy arrangements to avoid the discrimination inherent in such a dual system. As Trimmings and Beaumont warn, "the ECtHR jurisprudence will thus become a vehicle of the pro-surrogacy lobby groups that have commercial interests in the area of surrogacy in the receiving countries." 80

The developments before the European Court of Human Rights are too recent to determine which way states will move in this respect. Or if they will move at all, perhaps content to allow a two-tier system, despite its inherent inequalities. Whatever the outcome, states must recognise that their regulation of surrogacy can no longer be viewed as a domestic matter, isolated from the global market. Their choices are no longer solely their own.

\section{Conclusions}

As a result of these judgments, we can see that states have little recourse to prevent international surrogacy where there is a genetic connection, even if it is contrary to their own domestic law. While they can restrict travel for a short period of time, this is unlikely to be able to last indefinitely, and once the child is in the country, the parent-child relationship must be legally recognised. In reality, extraterritorial criminal prohibitions appear to be the only possible sanctions available to states, if they wish to have any real effect on circumvention tourism and the international surrogacy regime.

Trimmings and Beaumont, when devising a draft international convention on surrogacy, proposed that any surrogacy agreement undertaken outside the framework of the convention should be viewed as child trafficking, and criminalised as such. ${ }^{81}$ This has been the approach of the Australian states of New South Wales and Queensland, as well as the Australian Capital Territory, which have passed legislation prohibiting commercial surrogacy arrangements, giving extraterritorial effect for anyone ordinarily resident or domiciled within the state or territory. ${ }^{82}$ However, the Australian Family Law Council, in its recent review of the attribution of parentage under Australian federal law, noted that there is an apparent lack of interest in prosecuting people for breaches of such laws. ${ }^{83}$

\footnotetext{
79 (Appl. No. 57813/00) Judgment of 3 November 2011.

${ }^{80}$ Paul Beaumont and Katarina Trimmings, "Recent Jurisprudence of the European Court of Human Rights in the area of cross-border surrogacy: is there still a need for global regulation of surrogacy?" (2015, Working Paper) 11.

${ }^{81}$ Katarina Trimmings and Paul Beaumont, "International Surrogacy Arrangements: An Urgent Need for Legal Regulation at the International Level” (2011) 7 Journal of Private International Law 627.

${ }^{82}$ Surrogacy Act 2010 (NSW), s11; Surrogacy Act 2010 (Qld), s54(b); Parentage Act 2004 (ACT), s45(1).

${ }^{83}$ Family Law Council, Report on Parentage and the Family Law Act (December 2013) 86.
} 
Criminalisation would also leave children "subject to the taint of criminality" 84 as to criminalise a surrogate mother and/or commissioning parents for a surrogate birth is akin to criminalising the birth of the child himself or herself. The fact of that child's birth becomes a criminal offense. Even if we instead argue that the offence lies in entering into the arrangement, rather than the child's birth itself, such sophistry does not remove the taint that will surround the circumstances of the child's birth.

Furthermore, a threat of criminalisation may have the unintended consequence of driving the practice of surrogacy underground. In England, there is already substantial uncertainty concerning the number of surrogate births, as there is no requirement to formalise the arrangement through the legal system, leaving many children and women unprotected by the safeguards this provides. The availability of gestational surrogacy, which can be achieved without the assistance of medical professionals, means that individuals can potentially avoid any interaction with the authorities - medical or legal - in achieving their desire to become parents. Where such great concerns persist concerning exploitation, commodification and improper practices, we need to focus on bringing new families under the umbrella of the law, not driving them away from it.

In this way, we can see that we are at an impasse in relation to international surrogacy. We must accept that once the child is born, attempting to regulate surrogacy is useless. As the ECtHR has made clear, the best interests of the child must prevail, and the genetic tie between the parents and child must be converted to a legal one. Despite the strong words of Judge Dedov and the other concurring judges in Paradiso, for those who wish to prohibit surrogacy altogether, the future looks bleak.

\footnotetext{
${ }^{84}$ Report of the Committee of Inquiry into Human Fertilisation and Embryology (HMSO, London 1988)
} $\mathrm{Cm}$ 9314, 8.19. 